\title{
The Effect of Antibiotics on Lucilia sericata's Maggot in the Treatment of Patients with Osteomyelitis
}

Polat E ${ }^{1}$, Matlabi N2* and Kutlubay $\mathbf{Z}^{3}$

${ }^{1}$ Department of Medical Microbiology/Traditional, Istanbul University-Cerrahpaşa, Cerrahpaşa Faculty of Medicine, and Complementary Medicine Application and Research Center, Turkey

${ }^{2}$ Department of Medical Microbiology, Istanbul University-Cerrahpaşa, Cerrahpaşa Faculty of Medicine, Turkey

32Department of Dermatology and Venereal Diseases/

Traditional, Istanbul University-Cerrahpaşa, Cerrahpaşa Faculty of Medicine, Turkey

*Corresponding author: Naser Matlabi, Department of Medical Microbiology, Istanbul University-Cerrahpaşa, Cerrahpaşa Faculty of Medicine, Turkey

Received: April 13, 2021; Accepted: May 08, 2021; Published: May 15, 2021

\section{Introduction}

Osteomyelitis, also known as bone inflammation, is caused by pyogenic bacteria inoculation, directly or through the blood circulation into the bone. Many bacteria, especially Staphylococcus aureus, can cause osteomyelitis. These bacteria can be transmitted through fractures, penetrating injuries, or surgical procedures. Osteomyelitis, which can be seen in almost all age groups, was common in the past but has recently decreased due to antibiotic use [1]. If osteomyelitis is not treated due to clinical, economic and social conditions, the patient is given an amputation of the organ. Failure in amputation site's improvement poses another problem for the patient. Today, in the treatment of osteomyelitis; conventional methods such as antibiotic therapy, hyperbaric oxygen therapy, vacuum therapy, surgical debridement, drainage and removal of foreign bodies are used [2-4]. In the treatment of osteomyelitis caused by bacteria, L. sericata type fly maggot, which have bacteriositatic and bactericidal effects on bacteria, can also be used. The maggot of this fly species feed only on dead tissues and do not cause any damage to healthy tissues [5]. The maggot dissolve necrotic tissues with the enzymes they secrete, eat the microorganisms in the wound and disinfect the wound by showing bacteriostatic and bactericidal effects on these microorganisms. At the same time, maggot, which initiate tissue granulation and activate growth factors, provide rapid improvement of wounds [6-7]. Because of these features, MDT has been used in the treatment of injured organs that have been hardly healed or faced non-healing amputation decisions since 2007. Due to the successful results, amputations caused by wounds were prevented. The completely natural treatment method has no side effects on personnel or the environment. In this study, the treatment of 257 cases of osteomyelitis diagnosed with antibiotics, surgical curettage and drainage, removal of foreign bodies, vacuum and hyperbaric oxygen treatments were decided to be amputated with $L$. sericata maggot and antibiotics.

\section{Patients and Methods}

Between 01.01.2008-31.12.2018, a 4-year-old girl with osteomyelitis, 73 (28.4\%) female and $183(71.6 \%)$ male, applied to our unit. The patients were informed about the maggot treatment, the consent forms were filled in and signed by the patient who accepted the treatment. In 2006, the treatment of maggot, which was approved by ethics committee article 14620, is planned to be implemented. The wounds of the patients were cleaned with sterile saline; the photographs were taken, the material was taken to determine the bacteriological culture and antibiotic sensitivity and were sent to the medical microbiology laboratory (Figure 1A). Depending on the size and depth of the wound, stage I or II, larvae were placed on the wound and covered with a sterile sponge. Patients were advised to change the dressing frequently to keep the wound humid. Maggots were thrown into the garbage after being kept on the wound for 48-72 hours. This process was done twice a week. Maggot treatment was applied twice a week until the necrotic tissue in the wound was completely cleaned, bacteria did not grow in the materials taken and the bad smell from the wound disappeared. It was administered once a week, once every two weeks, or once a month in the progressive treatment process. If the wound did not improve during the controls, treatment of the maggot was continued [8-9].

\section{Results}

While some of the patients diagnosed with osteomyelitis have partial skin loss involving the epidermis, dermis or both, the wound of some of them was in the form involving all skin layers necrotization. Therefore, the wounds of these patients were evaluated as grade 3 and 4 . Our youngest patient was 4 years old, and the oldest patient was 90 years old. The distribution of patients with a mean age of 58.9 
Table 1: Non-healing wounds after amputation and their location.

\begin{tabular}{|c|l|c|c|}
\hline \multicolumn{2}{|l|}{ Non-Healıng Wounds after Amputation } & Case & $\%$ \\
\hline 1 & Amputee below the right knee & 3 & 2.5 \\
\hline 2 & Ampute below the left knee & 5 & 4.2 \\
\hline 3 & Right foot amputated & 6 & 5 \\
\hline 4 & Left foot is amputated & 4 & 3.3 \\
\hline 5 & Left and right foot amputated & 4 & 3.3 \\
\hline 5 & All fingers on the right foot are amputated & 10 & 8.3 \\
\hline 6 & One or more fingers on the right foot are amputated & 42 & 35 \\
\hline 7 & All fingers on the left foot are amputated & 11 & 9.2 \\
\hline 8 & One or more of the fingers on the left foot is amputated & 35 & 29.2 \\
\hline TOTAL & 120 & 100 \\
\hline
\end{tabular}

according to age groups is; $1(0.44 \%) 4,8$ (3.1\%) 10-30, 41 (15.9\%) 30 50, 161 (62.6\%) 50-70, 46 (17.9\%) 70-90. The most patients were 161 people and $62.6 \%$ were between the ages of 50 and 70 . Osteomyelitis in patients; 237 (92.2\%) diabetes, 10 (3.9\%) burger, 1 (0.4\%) Behçet disease, 1 (0.4\%) burn, 3 (1.2\%) accident, 2 (0.8\%) 1 (0.4\%) was due to spinal cord tumor, $1(0.4 \%)$ was Kapaosi sarcoma, $1(0.4 \%)$ was caused by lupus and incurable wound.

The legs, feet or toes of $120(46.7 \%)$ of the patients who came to our maggot treatment polyclinic were amputated due to osteomyelitis (Table 1) and the others were given an amputation decision. Osteomyelitis of patients was usually on the toes and heel of their foot. However, some patients had osteomyelitis on their legs, on both of feet, one patient on the elbow, one patient had it on the right arm and ankle, and one patient had over the sternum. The bones of the patients were bruised and broken due to osteomyelitis. Normally, $171(66.5 \%)$ of the patients had pain, while $86(33.5 \%)$ had no pain. $63(36.8 \%)$ patients with pain and 19 (22.1\%) patients without pain, totally 82 patients discontinued the treatment after one or two larvae application. The treatment of 10 patients with severe circulatory problems was terminated by us, thus the number of patients who discontinued the treatment was 92 (35.8\%). From 165 patients with ongoing oteomyelitis treatment, 156 patients $(94.5 \%)$ were treated, but 9 patients (5.5\%) were untreated.

Before starting the treatment of maggot, there was one species in $88(34.2 \%)$ and two types of bacteria in $75(29.2 \%)$ of the materials taken from the wounds (Table 2). In others, Three or more bacterial species such as S. aureus, MRSA, MSSA, E. faecalis, G group $\beta$-hemolytic streptococcus, E. coli, P. aeruginosa, S. marcescens, $P$. stuartil, K. pneumonia, C. striatum, A. baumannii, P mirabilis, A. junii, S. maltophilia, E. aerogenes, E. cloacae, S. epidermidis, S. haemolyticus, P. stuartil, P. mirabilis, A. junii, S. maltophilia, E. aerogenes E. cloacae, M. morganii, K. Oxytoca, C. freundii grew. After three or four sessions of maggot treatment, bacteria did not grow in the obtained materials (Figures 1B). MDT was applied to the patients 7 times on average.

\section{Discussion}

Osteomyelitis is divided into 4 groups including; medullary, superficial, localized and common. Osteomyelitis is highly likely when ulcer depth is $>2 \mathrm{~mm}$ or ESR $>70 \mathrm{~mm} / \mathrm{h}$. In the presence of large and deep ulcerations, the underlying bone is likely to become

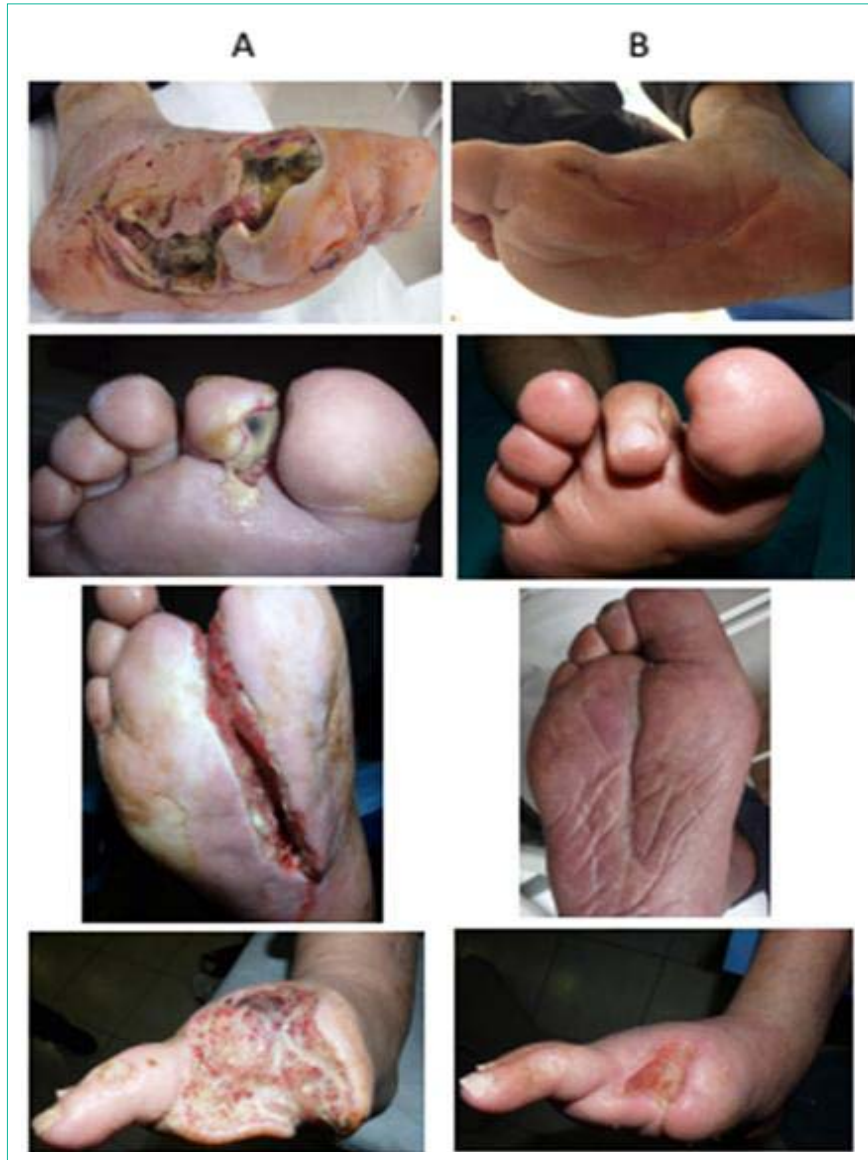

Figure 1: Effect of MDT on patients' wounnds A: Amputated region before MDTB: Amputated region after MDT.

infected. Osteomyelitis should be considered in the presence of visible or palpable bone at the base of the existing ulcer or nonhealing and non-ischemic ulcers. If osteomyelitis is suspected, the culture of the bone tissue sample that obtained during the surgical procedure or percutaneous biopsy will be appropriate [10,11]. The legs, feet or toes of $120(46.7 \%)$ of the patients who came to us for maggot treatment were amputated due to osteomyelitis (Table 1). But amputation wounds did not heal. Amputation decision was made for other patients with osteomyelitis since there was no improvement with conventional treatments.

The risk of chronic osteomyelitis is higher in patients with diabetes, those who use drugs for cancer treatment, the elderly, and those who smoke and consume alcohol. 237 (92.2\%) of the patients who developed osteomyelitis were diabetic.

Acute osteomyelitis, which is caused by bacteria spreading through the bloodstream and involving the bone, is mostly seen in children. Osteomyelitis, which occurs as a result of previous accidents, surgery and inability to treat the existing infection, is defined as chronic osteomyelitis, and it is mostly seen in adults [1]. From 257 patients who came to us with osteomyelitis; five of them were children and two had developmental and immunodeficiency problems. 161 (62.6\%) of the 252 adult patients were between the ages of 50 and 70 .

Many bacteria, especially S. aureus, can cause osteomyelitis 
Table 2: Bacteria Growing in Patients' Wounds.

Only One Bacterıa Specıes and Type, Producıng Osteomyelıtes and Number of Patıents

\begin{tabular}{|c|c|c|c|c|c|}
\hline \multicolumn{6}{|c|}{ Only One Bacterıa Specıes and Type, Producıng Osteomyelıtes and Number of Patıents } \\
\hline \multicolumn{2}{|r|}{ Bacterıa Species and Type } & \multirow{2}{*}{$\begin{array}{c}\text { Case } \\
7\end{array}$} & \multirow{2}{*}{$\begin{array}{l}\% \\
8\end{array}$} & \multirow{2}{*}{\begin{tabular}{|l} 
Bacterıa Species and Type \\
Pseudomonas sp.
\end{tabular}} & \multirow{2}{*}{$\begin{array}{c}\text { Case } \\
7\end{array}$} \\
\hline 1 & PK (-) staph & & & & \\
\hline 3 & MRSA & 8 & 10 & P. mirabilis & 4 \\
\hline 4 & C. striatum & 4 & 11 & K. pneumonia & 6 \\
\hline 6 & B G strepto & 4 & 13 & Acinetobacter sp. & 5 \\
\hline 7 & Enterobacter sp. & 2 & 14 & E. coli & 11 \\
\hline \multicolumn{2}{|c|}{ TOTAL } & 42 & & TOTAL & 46 \\
\hline
\end{tabular}

Two Bacterıa Specıes and Type, Producıng Osteomyelıtes and Number of Patıents

\begin{tabular}{|c|c|c|c|c|c|}
\hline \multicolumn{2}{|r|}{ Bacterıa Specıes and Type } & Case & $\%$ & Bacterıa Species and Type & Case \\
\hline 1 & S. aureus $+P$. aeruginosa & 4 & 15 & P. aeruginosa + Cirtobacte sp. & 3 \\
\hline 2 & S. aureus + Difteroid Çomak & 6 & 16 & $P$. auregınosa $+P$. stuartii & 1 \\
\hline 3 & S. aureus + Acinetobacter sp. & 3 & 17 & $P$. aeruginosa $+E$. coli & 4 \\
\hline 4 & S. aureus + Enterobacter sp. & 3 & 18 & Enterobacter sp. + Alcaligenes sp. & 1 \\
\hline 5 & S. aureus $+M$. morganii & 1 & 19 & S. macransis + C. freundii & 2 \\
\hline 6 & S. aureus + C. albicans & 3 & 20 & E. fecalis + Achromobacter sp. & 1 \\
\hline 7 & MRSA $+P$. aeruginosa & 4 & 21 & E. coli + S. epidermis & 5 \\
\hline 8 & MRSA + C. striatum & 2 & 22 & E. coli + Enterococcus sp. & 3 \\
\hline 9 & MRSA + P. rettgeri & 1 & 23 & P. stuartii + Klebsiella sp. & 1 \\
\hline 10 & MRSA + P. mirabilis & 2 & 24 & $K$. pneumone $+P$. mirabilis & 2 \\
\hline 11 & MRSA + MRPKNS & 2 & 25 & C. freundii + Serratia sp. & 3 \\
\hline 12 & Pseudomonas sp. + MRPKNS & 3 & 26 & S. maltophilia + C. striatum & 2 \\
\hline 13 & Pseudomonas sp. + Proteus sp. & 2 & 27 & S. marcescens + Candida sp. & 4 \\
\hline 14 & P. aeruginosa + Gr (+) difteroid çomak & 2 & 28 & K. pneumonia + C. tropicalis & 5 \\
\hline \multicolumn{2}{|r|}{ TOPLAM } & 38 & & TOPLAM & 37 \\
\hline \multicolumn{6}{|c|}{ More than Two Bacterıa Specıes and Type, Producıng Osteomyelıtes and Number of Patıents } \\
\hline \multicolumn{5}{|c|}{ Bacterıa Species and Type } & Case \\
\hline 1 & \multicolumn{4}{|l|}{ MRSA $+P$. vulgaris $+C$. amycolatum } & 1 \\
\hline 2 & \multicolumn{4}{|l|}{ S. aureus $+P$. aeruginosa $+P$. mirabilis } & 3 \\
\hline 3 & \multicolumn{4}{|l|}{ P. aeruginosa $+E$. coli $+P$. mirabilis } & 4 \\
\hline 4 & \multicolumn{4}{|l|}{ P. aeruginosa + E. coli + MRSA } & 5 \\
\hline 5 & \multicolumn{4}{|l|}{$P$. aeruginosa $+E$. coli $+C$. striatum } & 2 \\
\hline 8 & \multicolumn{4}{|l|}{$P$. aeruginosa $+P$. stuartii + Enterococcus sp. } & 1 \\
\hline 9 & \multicolumn{4}{|l|}{ P. aeruginosa + E. fecalis $+S$. aureus } & 5 \\
\hline 10 & \multicolumn{4}{|l|}{ E. coli + M. morganii + S. maltophilia } & 1 \\
\hline 11 & \multicolumn{4}{|l|}{ E. coli + A. baumannii $+P$. mirabilis } & 2 \\
\hline 12 & \multicolumn{4}{|l|}{ E. coli + A. baumannii + S. aureus } & 3 \\
\hline 13 & \multicolumn{4}{|l|}{ E. coli $+P$. mirabilis + E. faecalis } & 5 \\
\hline 14 & \multicolumn{4}{|l|}{ E. coli + C. striatum + E. fecalis } & 3 \\
\hline 15 & \multicolumn{4}{|l|}{ E. coli $+C$. striatum $+P$. rettgen } & 1 \\
\hline 16 & \multicolumn{4}{|l|}{ M. morganii $+C$. striatum + S. epidermidis } & 3 \\
\hline
\end{tabular}




\begin{tabular}{|c|c|c|}
\hline 17 & S. maltophilia $+A$. radioresistens $+E$. fecalis & 1 \\
\hline 18 & S. aureus + E. coli + M. morganii + Enterococcus sp. & 2 \\
\hline 19 & S. aureus $+P$. aeruginosa $+M$. morganii $+S$. agalactiae & 3 \\
\hline 20 & S. aureus + A. ursingii + S. maltophilia + E. fecalis & 1 \\
\hline 21 & S. aureus $+M$. morganii $+A$. haemolyticus $+B$ grubu streprococcus & 1 \\
\hline 22 & Pseudomonas sp. + Acinetobacter sp. + P. mirabilis + Staph & 4 \\
\hline 23 & P. aeruginosa + S. maltophilia + Alcaligenes sp. + Corynebacterium sp. & 1 \\
\hline 24 & P. aeruginosa $+E$. coli $+M$. morganii $+S$. aureus & 3 \\
\hline 25 & P. mirabilis + P. stuartii + Cirtobacter sp. + Enterococus sp. & 4 \\
\hline 26 & MRSA + Proteus sp. + Enterococcus sp. + B grubu streprococcus & 1 \\
\hline 27 & E. coli $+K$. oxytoca + C. freundii + Enterobacter sp. + Corynebacterium sp. & 1 \\
\hline 28 & MRSA + M. morganii + E. coli $+P$. alcalifacie + Difteroid çomak & 2 \\
\hline 30 & P. aeroginosa $+K$. pneumonia $+P$. mirabilis $+A$. baumannii + E. cloacate & 3 \\
\hline 31 & $P$. aeruginosa $+E$. coli $+P$. mirabilis $+A$. baumannii $+M$. Morganii & 1 \\
\hline 32 & MRSA + E. coli + K. pneumonia + S. agalactiae + Corynebac sp. + Enterococcus sp. & 3 \\
\hline 33 & E. aerogenes $+P$. mirabilis + S. marcescens + MRSA + C. striatum + E. faecalis & 3 \\
\hline 34 & E. coli + S. marcescens + Pseudomo sp. + Klebsiella sp. + S. aureus + Enterococcus sp. & 1 \\
\hline 35 & E. coli + S. marcesscens $+K$. oxytoca + E. fecalis $+P$. stuartii + Enterobacter $\mathrm{sp}$. & 3 \\
\hline 36 & P. aeruginosa + A. baumannii + E. coli + Acinetoba sp. + Proteus sp. + Difteroid Çomak & 2 \\
\hline 37 & Pseudomonas sp. + E. coli + S. marcescens + Klebsiella sp. + S. aureus + Enterococcus sp. & 1 \\
\hline 38 & M. morganii $+P$. mirabilis $+P$. retrigeri + Acinetobacter sp. $+S$. aureus $+C$. striatum + B grubu streprococcus & 1 \\
\hline 39 & $P$. aeruginosa + M. morganii $+E$. aerogenes $+K$. pneumoiae $+P$. stuartii $+P$. mirabilis $+E$. coli $+S$. aureus & 1 \\
\hline
\end{tabular}

$[1,9]$. Staphylococcus type bacteria grew in $92(35.8 \%)$ of the bacterial cultures we made. 45 (48\%) of these bacteria belonged to S. aureus, 24 (26.1\%) to MRSA and 23 (25.0\%) to other Staphylococcus species. Pseudomonas genus bacteria grew on the wounds of $47(18.3 \%)$ patients. 41 (87.2\%) P. aeruginosa, 6 (12.8\%) Pseudomonas sp. was. When the patients came to our outpatient clinic, they were using several types of antibiotics. In bacterial culture, one or more types of bacteria grew on the wounds of all patients and these bacteria were resistant to antibiotics. However, after 3-4 sessions of maggot treatment, no bacteria had grown in the materials we obtained.

Symptoms such as tenderness over the infected bone, skin rash, warmth, pus discharge from the open wound around the bone, and limitation of movement are observed in osteomyelitis [1]. The bones seen at the base of the ulcer in the patients were usually decayed and fragmented into many pieces. Even in wounds that did not heal after amputation, there were many bruised bones and fragments. Even after applying MDT 3-5 times, it was seen that a large number of bruised bone fragments came out of the tissue with the push of formed healthy tissues by the effect of the maggots and their secretion. Ulcers in patients are usually between the ankle, heel and ankle and knee; There was a large, widespread, necrotic, infected, purulent and severe odor. While 171 (66.5\%) of the patients had pain, 86 (33.5\%) had no pain. 63 (36.8\%) of $171(66.5 \%)$ patients with pain stopped the treatment due to excessive pain after applying MDT once or twice.

Osteomyelitis treatment is usually done according to the severity of the symptoms. Antibiotics and analgesics are among the most commonly used treatment methods [1-4]. Antibiotics, hyperbaric oxygen, vacuum and classical treatments were applied to the patients for a long time. If there is inflammation in the bone, the area is surgically opened and the inflammation is cleared. After inflammation cleansing, the area is closed again. Before starting chronic osteomyelitis treatment, the spread and discharge of inflammation in the infected area are evaluated. During the operation, whole dead bone tissue is removed, like tumor surgery [1]. Patients' wounds have been surgically debrided several times.

With the proteolytic enzymes they produce, the maggots debride necrotic tissues by melting and eating them quickly and effectively without damaging the living tissue. The photophobia maggots easily enter the places where the surgeon's scalpel cannot enter and remove the dead tissue by dissolving (it) [12-14]. The maggots produce a hydrophobic peptide-like 3-10 kDa and hydrophilic $1 \mathrm{kDa}$ antibacterial substances that disinfect the wound by showing bacteriostatic and bactericidal effects on bacteria in the wound $[6,9,15]$.

Sherman demonstrated in in-vitro studies that live maggots have bacteriostatic and bactericidal effects on pathogenic bacteria such as S. aureus, group A and group B streptococci [16].

Huberman et al., In 2007, determined that substances secreted by $L$. sericata maggots, by weighing 138, 152 and $194 \mathrm{kDa}$; have antibacterial activity against Gram-positives [(Methicillin-Susceptible $S$. aureus (MSSA), Methicillin-Resistant S. aureus (MRSA)] and Gram- 
negatives (P. aeruginosa, S. marcescens, E. coli and K.pneumoniae) [6 ].

Thomas et al. Demonstrated that maggots can be used in the treatment of various types of wounds infected with antibioticresistant agents by treating 5 lesions caused by Methicillin-Resistant S. aureus (MRSA), consisting of 3 pressure ulcers, 1 pilonidal sinus and 1 large abscess [7].

Patients do not look favorably at MDT at the beginning, as they do not believe that their wounds will be cured with worms and find it disgusting to put worms in their wound. Therefore, patients primarily prefer antibiotics, hyperbaric oxygen, vacuum, classical treatment methods and surgical debridement. However, patients who cannot get results from these treatments and those who decided to have amputations choose to come to MDT as a last resort. If antibiotic treatment was given to the patients who came to our polyclinic, it was continued. However, since bacteria grow in the materials taken from the wounds of the patients, antibiotic treatment was not given again after the antibiotics they used were finished. However, if there are inflamed parts in the wound that the maggots cannot reach, Ornidazole and Ciprofloxacin were given to the patients and continued until the inflammation dried. Maggots that constantly need oxygen do not enter places where there is no oxygen and anaerobic bacteria grow.

Primary closure, skin grafts, local skin flaps, muscle-skin flaps, fasciocutaneous flaps and neurosensory flaps are used for wound closure after surgical debridement. However, it cannot be guaranteed that no new wounds will be created after any type of closure. There is no need to close the wounds in MDT because they close by themselves. With the effect of maggot secretion, the expression of many genes and the expression level of miRNAs changes in the early period ( $4^{\text {th }}$ day), middle period ( $7^{\text {th }}$ day) and last period $\left(10^{\text {th }}\right.$ day). These, in turn, affect the restructuring of the extracellular matrix, cell proliferation, cell migration, angiogenesis, the formation of collagen (destruction and restructuring) and the inflammation process. It was observed by us that no new wounds were opened in the places of the wounds closed with maggot treatment for 10 years, but new wounds formed elsewhere [17-19].

Digestion and hemolymph secretions of the maggots stimulate fibroblast cells to concentrations of Epidermal Growth Factor (EGF), stimulating fibroblast tissue growth. It has been determined that maggot extracts or EGF stimulate fibroplasia by a different mechanism or have a synergistic effect. Maggot secretions prevent the tissue damage of neutrophils and their products (proteolytic enzymes, reactive oxygen intermediates), which have a negative effect on the wound surface during the improvement process of chronic wounds [20]. Inhibits neutrophil chemotaxis against fMLP (N-formyl-methionine-leucine-phenylalanine). The expression of the adhesion molecules CD11b and CD18 is reduced on the activated neutrophils that allow neutrophils to adhere to endothelial cells. This inhibitory activation of maggot secretions prevents the destruction of neutrophils in chronic wounds and suppresses the proinflammatory response of neutrophils without impairing their anti-microbial activities. Wound debridement accelerates in tissues that begin to grow with the stimulation of tissue granulation [17-19,21,23].

Because of these effects of maggot secretions and the stimulating movements of living maggots placed on the wound, wounds treated with MDT improved faster than conventional treatment. We think that using MDT together with other treatments in the treatment of all open wounds regardless of the underlying causes will contribute to the rapid healing of wounds. Solutions such as povidone-iodine, hydrogen peroxide, acetic acid, sodium hypochlorite, silver sulfadiazine used for topical wound care should not be used after maggot debridement because these solutions damage the tissue granulation stimulated by maggot secretion and degeneration and the tissues that begin to grow. The ideal material to be used after debridement is saline.

\section{References}

1. Yıldız Ş, Pehlivan Ö, Ay H, Mahiroğulları M, Kuşkucu M, Akmaz İ. Kronik osteomyelit olgularında HBO tedavisi. Gülhane Tıp Dergisi. 2004; 46: 189193.

2. Aktaş Ş. Hiperbarik oksijen tedavisi: Yara tedavisindeki yeri. In: Erdost ŞK, Çetinkale O, editörler. Yara Bakımı ve Tedavisi. İstanbul: İ.Ü. Cerrahpaşa Tıp Fak. 2008; 199-206.

3. Aktaş Ş. Kronik yara tedavisinde vakum yardımlı kapama. In: Topalan M Aktaş Ş, editörler. Güncel Yönleriyle Kronik Yara. İstanbul: İ.Ü. İstanbul Tıp Fak. 2010; 194-207.

4. Erdoğan B. Yara bakım ürünleri. In: Topalan M, Aktaş Ş, editörler. Güncel Yönleriyle Kronik Yara. İstanbul: I.Ü. İstanbul Tıp Fak. 2010; 143-71.

5. Bonn D. Maggot therapy: an alternative for wound infection. Lancet. 2000; 356: 1174.

6. Huberman L, Gollop N, Mumcuoglu KY, Block C, Galun R. Antibacterial properties of whole body extracts and haemolymph of Lucilia sericata maggots. J Wound Care. 2007; 16: 123-127.

7. Thomas S, Andrews A, Jones M. The use of larval therapy in wound management. J Wound Care. 1998; 7: 521-524.

8. Polat E. Larva Debridman Tedavisi (LDT). Güncel yönleriyle kronik yara. In: Topalan M, Aktaş Ş, editörler. İstanbul Tıp Fakültesi Kronik Yara Konseyi. 1. baskı. İstanbul: Aygül Ofset Matbaacılık. 2010; 181-93.

9. Bolaban D. Lucilia sericata larvaları ve salgılarının metisiline dirençli Staphylococcus aureus (MRSA) ve metisiline duyarlı Staphylococcus aureus (MSSA) üzerine antibakteriyel etkilerinin in-vivo ve in-vitro koşullarda araștırılması. Master thesis, Istanbul Universty Health Sciences Institute. 2009.

10. Sherman RA. A new dressing design for use with maggot therapy. Plast Reconstr Surg 1997; 100: 451-456.

11. Oto M. Diagnosıs of chronıc osteomyelıtıs and value of medıcal-surgıcal treatment combınatıon. Pamukkale Tıp Dergisi. 2008; 1: 50-58.

12. Sherman RA. Maggot versus conservative debridement therapy for the treatment of pressure ulcers. Wound Repair Regen. 2002; 10: 208-214.

13. Brin YS, Mumcuoglu KY, Massarwe S, Wigelman M, Gross E, Nyska M. Chronic foot ulcer management using maggot debridement and topical negative pressure therapy. J Wound Care. 2007; 16: 111-113.

14. Mumcuoglu KY, Ingber A, Gilead L, Stessman J, Friedmann R, Schulman H, et al. Maggot therapy for the treatment of diabetic foot ulcers. Diabetes Care. 1998; 21: 2030-2031.

15. Mumcuoglu KY, Miller J, Mumcuoglu M, Friger M, Tarshis M. Destruction of bacteria in the digestive tract of the maggot of Lucilia sericata (Diptera: Calliphoridae). J Med Entomol. 2001; 38: 161-166.

16. Sherman RA. A new dressing for use with maggot therapy. Plastic and Reconstructive surgery 1997; 100: 451-456.

17. Sherman RA. Maggot versus conservative debridement therapy for the treatment of pressure ulcers. Wound Repair Regen. 2002; 10: 208-214.

18. Brin YS, Mumcuoglu KY, Massarwe S, Wigelman M, Gross E, Nyska M. Chronic foot ulcer management using maggot debridement and topical 
negative pressure therapy. J Wound Care 2007; 16: 111-113.

19. Mumcuoglu KY, Ingber A, Gilead L, Stessman J, Friedmann R, Schulman H et al. Maggot therapy for the treatment of diabetic foot ulcers. Diabetes Care. 1998; 21: 2030-2031.

20. Polat E, Kutlubay Z, Sirekbasan S, Hilal Gökalp H, Akarırmak Ü. Treatment of pressure ulcers with larvae of Lucilia sericata. Turk J Phys Med Rehab. 2017; 63: 307-312.

21. Polat E, Aksöz I, Arkan H, Coşkunpınar E, Akbaş F, Onaran İ. Gene expression profiling of Lucilia sericata larvae extraction/secretion-treated skin wounds. Gene. 2014; 550: 223-229.
22. Coskunpinar E, Arkan H, Dedeoglu BG, Aksoz I, Polat E, Araz T, et al. Determination of effective miRNAs in wound healing in an experimental Rat Model. Cell Mol Biol (Noisy-le-grand). 2015; 61: 89-96.

23. Prete PE. Growth effects of Phaenicia sericata larval extracts on fibroblasts: mechanism for wound healing by maggot therapy. Life Sci. 1997; 60: 505510. 